\title{
Integrating Learning Development into the Student Experience
}

\section{Pat Hill}

University of Huddersfield, UK

\section{Amanda Tinker}

University of Huddersfield, UK

\begin{abstract}
'Embedding skills' has become an educational buzz word which evokes many different responses. Whilst acknowledging this diversity, this article focuses on the promotion of the integration of skills development into the subject curriculum as theory is put into practice. A range of attitudes towards integrated learning development are discussed and there is an attempt to define the generic principles associated with integration. Different models of embedding are provided through case studies available on a new website developed as part of a university funded Teaching and Learning Project. The journey towards a more strategic level of integration though the course validation process is outlined along with ideas for continued progress.
\end{abstract}

Keywords: embedding skills; integrated learning development; curriculum design; student experience; institutional change.

\section{Introduction}

Changes to the funding of higher education present new challenges; meeting these challenges requires innovative approaches to enhancing the quality of the student experience. There is strong evidence that students benefit from the integration of learning development strategies into the core curriculum, and one of the key motivators for embedding skills is 'the principle that students and staff place more value on activities where they form a seamless part of their programmes' (Bloxham, 2004, p.2). Tamsin 
Haggis (2006, p525) contributes another important perspective to the debate when she suggests that the question we ask should be altered from "What is wrong with this student?' to 'What are the features of the curriculum, or of processes of interaction around the curriculum, which are preventing some students from being able to access this subject?". This is important to learning developers as a whole as it moves the impetus away from the individual student to the realm of curriculum design, thus removing some of the notion of student deficit. It is also important to note that although embedding strategies do not replace the proven value of one-to-one contact, they can reach the majority of students who, for various reasons, do not have the advantage of, or take the opportunity provided, by such provision (Hill et al., 2010).

Putting the theory of embedding or integrating skills development into practice is one of the key themes of this paper. Ursula Wingate, a lecturer in the Department of Education and Professional Studies at King's College, London, although she deals exclusively with writing skills, provides a useful model for moving integration from theory to practice. Her widely cited article 'Doing away with 'study skills"written in 2006, clearly resonated with the higher education community (Wingate, 2006). She subsequently obtained funding to pilot the embedding of writing skills into modules at her institution and $100 \%$ of the academics involved agreed on the effectiveness of the embedded approach for the teaching of writing (Wingate et al., 2011). The current paper details how a student-centred perspective has developed into a more strategic, institutional one; it is also important to note that from an institutional perspective, proponents such as Manalo et al. (Executive summary, 2010) illustrate the advantages of such integration to institutions such as 'better retention and completion rates'. This is particularly relevant in light of current changes in higher education and the new challenges it brings.

These challenges include increased institutional competition and higher fees, which make the NSS survey on student satisfaction more prominent and raise student expectations in terms of value for money. Employability has also become a more important focus both for students and institutions. In the current economic climate, institutions also need to increase efficiency in reaching a larger number of students with fewer resources. Craig Mahoney, Chief Executive of the Higher Education Academy, suggests:

Cuts in resource and changes to student finance will increase the challenge of sustaining and improving student satisfaction...HEls will need to concentrate on 
support for learning and teaching as prospective students, parents and sponsors expect outstanding learning across the sector (Mahoney, 2011).

As the quality of the student learning experience becomes a focal point, institutions need to promote a philosophy of learning which is not simply based on a transfer of knowledge but which encourages students to develop the 'skills to allow them to fully participate in the university learning experience, to develop a sense of 'graduateness' and to enhance employability' (Gerrard et al., 2005). Embedding the teaching of such skills into the curriculum, however, requires an institution-wide understanding of the complexities involved in developing skills where context, dialogue, reflection and motivation are key elements; relevance and timeliness being other major factors (Drew, 2004). This institution-wide approach was strongly advocated by Lisa Ganobcsik-Williams in a report on the teaching of academic writing commissioned by the Royal Literary Fund (GanobcsikWilliams, 2004). In response to a university wide call for Teaching and Learning projects in 2009, learning developers (LDs) and a senior academic at the University of Huddersfield were successful in gaining funding to examine existing institutional strategies for integrating learning development into the curriculum in order to enhance the student experience (at the time, the majority of the LDs were named 'Academic Skills Tutors' (ASTs) but some have now opted for the term 'Learning Developer' and this has been used throughout this article as a more generic term). This paper details the process and key findings of the project along with future directions.

\section{Method}

As the investigation across the university began, one pertinent aim was to achieve some understanding of academic staff perceptions and attitudes towards embedding skills development within the curriculum. To this end, a one question, anonymous, crossuniversity email was sent, asking: 'What does embedding skills in the curriculum mean to you?'. Following analysis of this survey, the project leaders at Huddersfield took a decision to 'work with the converted'. The idea was to create a resource that would allow us to showcase successful examples of embedding in order to convince others of its positive benefits and illustrate different ways in which it could be achieved. The main team behind the project were two LDs, one principal lecturer and one technician, but all LDs across the various Schools collaborated in sourcing information. The rationale (see Appendix 1) was 
distributed to all LDs and library staff with a request to provide examples of good practice within the Schools to which they were attached. Sent along with this rationale was a skills list of undergraduate and graduate attributes compiled from various sources such as Yorke (2006). A 'Mapping template' was also produced which asked subject departments to illustrate where specific skills were practised and, if they were taught, who taught them (See Appendix 2). Not all Schools completed the template, but it was made obvious from the returned templates that some of the skills listed were being required and assessed but not being explicitly taught. Based on the feedback from the templates and LDs, individuals were contacted for details of case study modules where skills have been successfully integrated into the curriculum and it is these case studies that form the basis of the project's newly developed website: http://embeddingskills.hud.ac.ukl.

The website was created using an open source tool, Drupal (http://drupal.org/). This choice was made after research showed that this tool is freely available, reliable and is successfully used within the university (http://ipark.hud.ac.uk/). Drupal supports a multidimensional, faceted search that is invaluable in dealing with complex case studies, and allows the user to access information from a variety of perspectives. Through an analysis of these case studies a classification scheme was developed based on four facets: course level; delivery method; skill; student task. Through this faceted search, the reader can explore a variety of practices within the university and have access to relevant resources on a whole range of skills. These include all levels from pre-foundation to post-graduate.

\section{Project outcomes}

The move towards embedding or integrating skills development is not without opposition as some subject staff still believe that their job is to impart only subject specific skills and content, and that generic skills are a separate entity that should already be known by students or taught remedially. The one question survey referred to earlier resulted in 90 responses. These were analysed to generate themes and the following table illustrates the diverse range of opinion. 


\section{Table 1. Academic perceptions of what 'embedding skills' means.}

\begin{tabular}{|c|c|}
\hline Integrated & $\begin{array}{l}\text { 'It can mean different things according to context...but the word } \\
\text { 'embedding' implies that something is to be integrated, not added on } \\
\text { at the end or done separately'. } \\
\text { 'Teaching skills as part of academic modules in a particular subject } \\
\text { area rather than teaching them in a generic skills module or through } \\
\text { additional support mechanisms such as Academic Skills Tutors'. } \\
\text { 'This would mean to me that skills are integrated into a curriculum } \\
\text { from start to finish so they have core value and presence in all } \\
\text { individual modules that make up the curriculum'. }\end{array}$ \\
\hline Progressive & $\begin{array}{l}\text { '...the integration of critical thinking, to inform study and critical } \\
\text { writing, to inform the demonstration of understanding and application } \\
\text { of knowledge, into each stage of a student's journey through their } \\
\text { degree. Each year stage is different requiring incrementally different } \\
\text { skills'. } \\
\text { '...the teaching, learning (hopefully!), practice and assessment of } \\
\text { core practical skills. The assessment must be through practical } \\
\text { assignments designed to show proficiency in such core skills, } \\
\text { building them incrementally'. } \\
\text { 'It would seem that generic skills/transferable skills relating to } \\
\text { communication, analysis, interpretation and synthesis for example } \\
\text { are important factors in any discipline at an early stage of the course. } \\
\text { In relation to the area of art and design these need to be developed } \\
\text { in tandem with skills of practice, judgement and critique with the } \\
\text { notion of 'progression'. Quite often 'skills' remain remote if given as } \\
\text { an 'introductory' stage - they should be part of the diagnostic } \\
\text { process in developing the learner and the dialogue that happens in } \\
\text { teaching and learning. The 'curriculum' becomes more flexible and } \\
\text { holistic if 'skills' are related to the innate processes of the discipline } \\
\text { and re-introduced at key stages and as part of the continuing } \\
\text { development of the individual's profile'. }\end{array}$ \\
\hline
\end{tabular}




\begin{tabular}{|c|c|}
\hline $\begin{array}{l}\text { Implicit or } \\
\text { Explicit? }\end{array}$ & $\begin{array}{l}\text { '...the skills component is not, in general, learnt separately to the } \\
\text { content but is an implicit part of the content. The skills component } \\
\text { might be more explicitly drawn out at various stages, but certainly } \\
\text { wouldn't be learnt on its own to start with, and wouldn't be given } \\
\text { extra space in the curriculum (e.g. a study skills module)'. } \\
\text { 'To me it means providing transferable skills invisibly within the } \\
\text { curriculum. It means ensuring they are there. But it may be implicit } \\
\text { rather than explicit'. } \\
\text { 'If skills are truly embedded students shouldn't be aware that they } \\
\text { are learning them, as opposed to the subject material, and the } \\
\text { delivery should be by the core academic staff'. } \\
\text { '...the coursework and exercises in the curriculum would act as } \\
\text { incubation and development of specific skills, not necessarily } \\
\text { explicitly'. } \\
\text { 'It means that the curriculum is written in such a way that the skills } \\
\text { needed to achieve the overall learning outcomes/specific standards } \\
\text { are identified and made transparent'. }\end{array}$ \\
\hline Remedial & $\begin{array}{l}\text { 'It means cutting back on genuine academic content. It also means } \\
\text { patronising our 18-21 year old students with Mickey Mouse bullshit } \\
\text { they've already learned in school and patronising our mature } \\
\text { students by treating them like school kids'. } \\
\text { 'Either they should be taught and assessed explicitly (and hence be } \\
\text { part of the curriculum) - and that might be true of chemistry lab skills } \\
\text { - or they should be assumed as part of what any undergrad should } \\
\text { already know - and this applies to most study skills. Of course some } \\
\text { students may lack the latter skills, in which case they need remedial } \\
\text { work - but that is what it is, remedial, not a core content of the } \\
\text { curriculum at university'. } \\
\text { 'For undergrads that come straight from formal education, it means } \\
\text { that their formal education has been insufficient. Students with a } \\
\text { solid set of A levels or equivalent (UCAS entry for my Course is 280) } \\
\text { should, in my opinion, be able to write in grammatically correct } \\
\text { English, have a good understanding of syntax and be able to } \\
\text { structure written work coherently. The fact that many students do not }\end{array}$ \\
\hline
\end{tabular}




\begin{tabular}{|c|c|}
\hline & $\begin{array}{l}\text { have these skills means they miss out on subject content and higher } \\
\text { academic skills whilst academics teach them the difference between } \\
\text { 'weather' and 'whether'. }\end{array}$ \\
\hline $\begin{array}{l}\text { Putting theory } \\
\text { into Practice }\end{array}$ & $\begin{array}{l}\text { 'Simulation is a core process that to me allows me as a professional } \\
\text { to identify that my students are able to link theory to their practice } \\
\text { and are fit for purpose when out in the practical environment...' } \\
\text { 'Ensuring that where related skills are required by the student who } \\
\text { may also be a practitioner, that they are built in with supporting } \\
\text { Theory and Practice at the appropriate point in the programme'. } \\
\text { 'In professional or practice discipline curricula, it means the } \\
\text { integration of 'practice with theory' ('practice (skills) to theory') and } \\
\text { the linkage of 'theory to practice' -Bridging the theory-practice and } \\
\text { practice-theory gap'. }\end{array}$ \\
\hline Transferable & $\begin{array}{l}\text { 'It means, to me, that whatever items of coursework, projects, } \\
\text { presentations etc. that we ask students to do (in relation to specific } \\
\text { learning outcomes or assessment criteria) they will also help develop } \\
\text { key/transferable skills, ideally as a consciously designed element of } \\
\text { pedagogy in relation to previous, adjacent and subsequent tasks'. } \\
\text { 'It refers to a path towards cultural change where the 'skills' are } \\
\text { eventually 'taken for granted' by the students after applying them as } \\
\text { part of academic study. As an example, use of computers to search } \\
\text { for information is taught to students as part of their course but is not } \\
\text { the prime focus. This is a transferable skill that may be invoked } \\
\text { during any subsequent part of their study'. } \\
\text { 'It means identifying skills such as using the library and internet, } \\
\text { seeking material on a topic, using it in academic work, quoting from it } \\
\text { appropriately and using the Harvard referencing system within a } \\
\text { module which is compulsory but not specifically called 'study skills'. } \\
\text { So they learn the skill in context such as studying social policy. The } \\
\text { challenge is to repeat the skill in another context'. } \\
\text { 'The word 'skills' to me, always makes me think of something that } \\
\text { can be used at a later date in employment, after the student has } \\
\text { for cross-transferable skills in our modules and record what they are }\end{array}$ \\
\hline
\end{tabular}




\begin{tabular}{|l|l|}
\hline & $\begin{array}{l}\text { (for PDP purposes). Things like critical thinking, problem solving, } \\
\text { initiative, planning, collaboration etc.' } \\
\text { 'Knowledge - learning - application - confidence - your skills allow } \\
\text { you to build on forming an identity to enable you to form broader } \\
\text { career prospects with confidence'. }\end{array}$ \\
\hline $\begin{array}{l}\text { Assessed } \\
\text { and assessment task of activity which evidences the skills you're } \\
\text { trying to embed, together with clear direction on supporting } \\
\text { 'Using the core/generic skills, use of appropriate } \\
\text { language/nomenclature, referencing, research skills, appropriate } \\
\text { data analysis, use of IT etc., in a range of activities across a range of } \\
\text { different subjects. I assess them in many of the assignments which I } \\
\text { set (they are part of the marking scheme) however I feel a number of } \\
\text { colleagues pay lip-service to them. I set some challenging } \\
\text { assignments which draw on these core skills, I know exactly what } \\
\text { they have been taught and want to see it used hence doing } \\
\text { assignments like writing up in a journal format etc.'. }\end{array}$ \\
\hline
\end{tabular}

These responses show how complex the concept of embedding is, let alone the use of the term 'skills'. For some, the term evoked a very positive response aligned with professional development, but even these differ in that some colleagues saw it as integrating the development of graduate qualities seamlessly, and even 'invisibly' into the programme, whilst others felt it important to identify and record these skills explicitly. The more negative responses perceived a patronising and remedial approach in the move to embed skills. The challenge for LDs is to offer a range of strategies from which different colleagues can choose those which are appropriate and acceptable. Another interesting and important theme coming from the survey was the need for progression as the students move through their degree programme and this became more apparent on scrutinising the returned 'mapping templates'.

The Mapping Template was developed to provide a framework to assess a course holistically and objectively in order to identify where the necessary skills are practised and taught. Some very detailed work has been done on this by Tariq et al. (2004) but our aim was to keep this as simple as possible in order to engage staff and add as little as possible 
to workloads. The completed template can highlight any omission or repetition and signpost opportunities to embed learning development into the curriculum, providing a more seamless student experience, with skills input from the most appropriate source at the most appropriate time. In analysing the templates, it was apparent that input on skills development was heavily frontloaded with most of the teaching being done in the first year. There was some input in the third year as students approached a major piece of work, such as a dissertation, but in the second year it was clear that although skills were assessed, they were rarely taught. This finding links to research done by Grump (2007) and Schreiner (2010) who found that second year students often experienced particular problems of stress and lack of engagement. Using the templates appeared to highlight gaps and areas of repetition and inefficiency, and the project leaders are now working to promote a more holistic approach to curriculum design.

\section{Case Studies}

The project discovered many examples of innovative practice which integrate the teaching and learning of skills within the curriculum and it is these case studies that form the basis of the project's newly developed website http://embeddingskills.hud.ac.uk (see Figure 1).

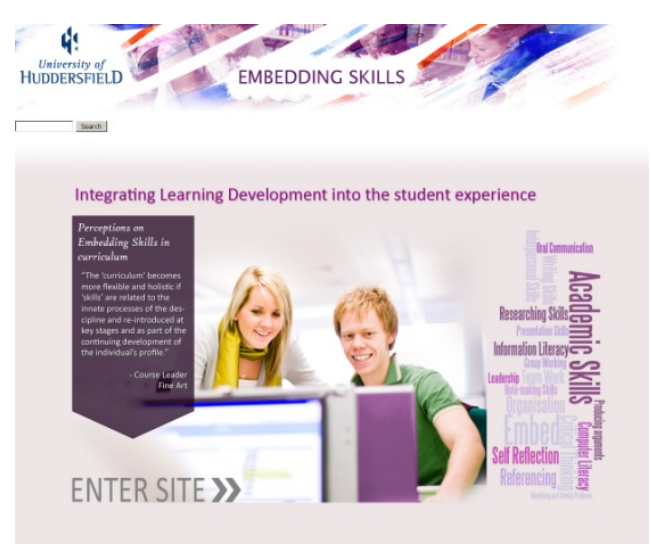

Figure 1. Home page.

Although the funding for the original project has finished, the team has taken on the responsibility to add to it as other modules come to light and to update it where possible as modules evolve; the possibility of expanding this website as a national resource is being actively explored via the Association for Learning Development in Higher Education's (ALDinHE) Continuing Professional Development Group. 
For each chosen case study a template was completed. This template includes a rationale, details of the module, ideas for adaptation, details of the innovators and usable resources. This template is also available on the website for users to contribute new case studies to add to the database. Case study resources include lecture notes, PowerPoint presentations, student activities, assignment briefs, tutor notes and links to valuable websites. The information includes all levels from pre-foundation to post-graduate (See Figure 2 below).

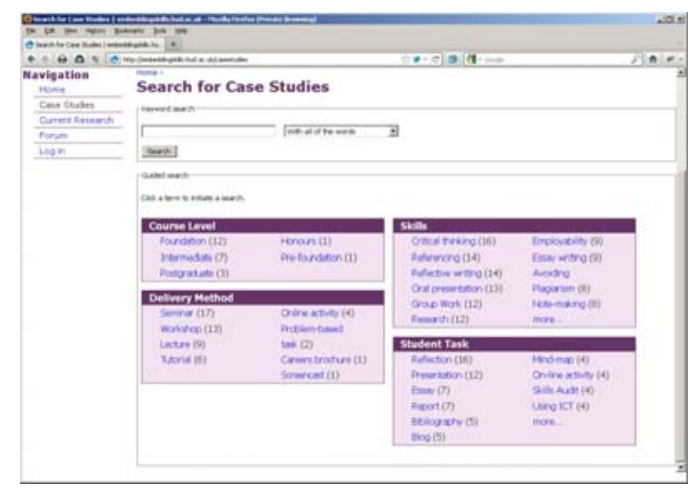

Figure 2. Case study faceted search.

The website also includes a repository of current research on embedding skills which will be updated annually.

A Set of Generic Principles for integrating learning development into the curriculum was extrapolated from research and case studies and these have been included on the website:

\footnotetext{
Collaborative

Integrated learning development requires collaboration of all those who are involved in the teaching and learning. This might include course leaders, module tutors, lecturers, learning developers, librarians, technicians, careers advisors and the students themselves, anyone who can contribute in providing the most effective learning experience for the student.

Holistic

It is important to consider the whole course rather than individual modules and levels of study when integrating learning development. This ensures that development takes place at an appropriate stage, eliminates unnecessary repetition and that all relevant areas are covered.
} 


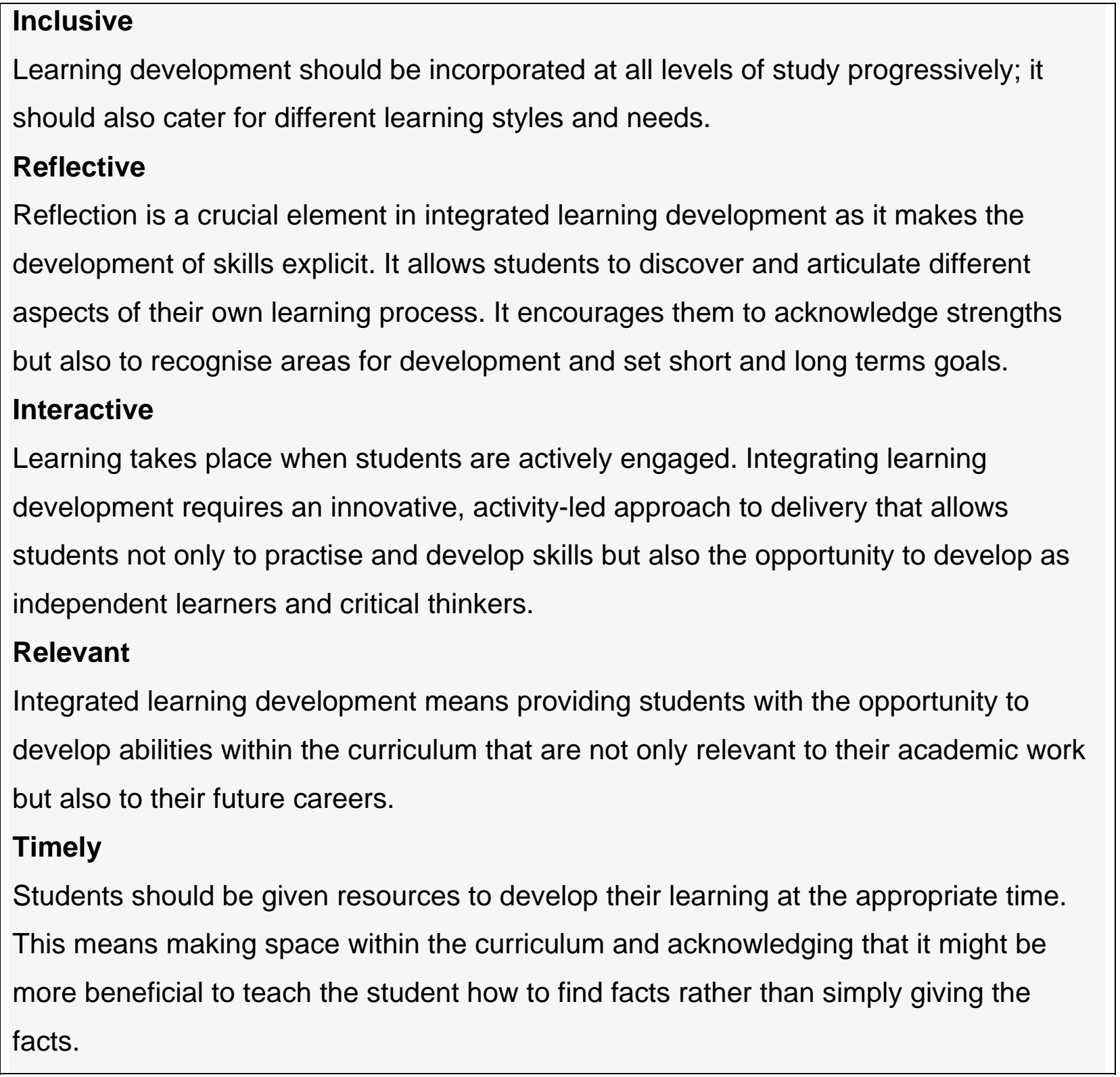

Table 2. A Set of Generic principles for Integrating Learning Development into the Curriculum.

Based on these principles, the project leaders are working to achieve the implementation of a progressive, multi-strategy approach for the timely and efficient integration of learning development within the curriculum at all course levels. In order to do this we recommended a change to University validation procedures through the University Teaching and Learning Committee (UTLC). We strongly suggested that the use of the website resources, for example the mapping template and the examples of good practice, become a necessary step in the curriculum design and validation process. This was accepted so that the Committee reported that they: 
...felt that the outcomes of the project emphasised the need to view the development of a course as a whole rather than being applied on a module basis. This approach would allow teams to capture the overall progression of a student across all taught years whilst identifying any gaps in delivery or duplication assessment. (8 November, 2011,Minute ref.5.3)

They required that in future '[Course] Teams should reflect their incorporation of skills development in the Teaching and Learning section of the Programme Specification Document'. This is a significant step forward in encouraging all staff to consider how important it is to give students the opportunity within the curriculum to develop and reflect on the graduate skills that they need. It has also given LDs strategic recognition and support from senior management in their continued efforts to enhance the student experience.

\section{Conclusion and future directions}

This article supports the need to integrate skills development within the curriculum. A recent QAA draft for consultation document on the 'UK Quality Code for Higher Education' (May, 2012, p.6) promotes 'The planning and design of learning and teaching activities [which]...provide effective teaching of subject-specific, transferable, practical and professional skills'. Although this has not yet been finalised, it shows a clear direction toward integration. The present article illustrates some of the complexity involved in this by outlining diverse attitudes and also attempts to move forward by bringing together a set of generic principles. Although the article outlines a successful project, it is important to acknowledge the many challenges faced in providing students with the opportunity to develop necessary and relevant skills within the curriculum.

We have recently acquired internal funding through the University of Huddersfield Teaching and Learning Innovation Projects 2013 scheme which we feel will build on the findings from the initial project. 'Second Year Blues: Developing Interactive Resources for Progressive Curriculum Design' is a new project which aims to develop strategies that might better embed progressive learning across the curriculum and, in particular, at intermediate level. The objectives include providing guidance, resources and ideas to promote innovative delivery of skills development. One of the key aims of the bid is also to 
gather evaluative data through staff and student interviews and focus groups. The results will be made available through the embedding skills website which is also to be further developed as part of a national resource through collaboration with ALDinHE.

\section{Acknowledgements}

We particularly need to acknowledge the invaluable technical contribution of Vidya Kanara and the management and guidance of Paul Squires (Principal Lecturer and Subject Leader in Textiles).

\section{References}

Bloxham, S. (2004) Embedding skills and employability in higher education: an institutional curriculum framework approach. Higher Education Academy [Online]. Available at: http://www.qualityresearchinternational.com/esecttools/esectpubs/bloxhamembeddi ng.pdf (Accessed: 15 November 2011).

Drew, S. (2004) 'How do you encourage usage of a computer based writing resource?', Writing Development in Higher Education Conference. Sheffield Hallam University, Sheffield, . 11-12 May.

Ganobcsik,-Williams, L. (2004) A report on the teaching of academic writing in UK higher education [Online]. Available at: http://www.rlf.org.uk/fellowshipscheme/documents/TeachingWritingUKHE.pdf (Accessed: 18 January 2012).

Gerrard, C., Tweedie, S. and McVey, D. (2005) Embedding effective learning skills in the curriculum: case studies and interventions. Scotland: University of Paisley.

Grump, S. (2007) 'Classroom research in a general education course: exploring implications through an investigation of the sophomore slump' The Journal of General Education, 56(2), pp. 105-125. 
Haggis, T. (2006) 'Pedagogies for diversity: retaining critical challenge amidst fears of 'dumbing down', Studies in Higher Education, 31(5) pp. 521-535.

Hill, P., Tinker, A. and Catterall, S. (2010) 'From deficiency to development: the evolution of academic skills provision at one UK university', Journal of Learning Development in Higher Education, Issue 2, February, pp. 1-19 [Online]. Available at: http://www.aldinhe.ac.uk/ojs/index.php?journal=jldhe\&page=article\&op=view\&path \%5B\%5D=54\&path\%5B\%5D=38 (Accessed: 21 May 2012).

Mahoney, C. (2011) HEA response to 2011 National Student Survey [Online]. Available at: http://www.heacademy.ac.uk/news/detail/2011/NSS results 2011 comment Craig Mahoney (Accessed: 18 January 2012).

Manalo, E., Marshall, J. and Fraser, C. (eds.) (2010) Student learning support programmes that demonstrate tangible impact on Retention, Pass Rates and Completion. Aotearoa (N.Z.): Ako Aotearoa Northern Regional Hub.

QAA (2012) UK Quality code for higher education. Chapter B3: Learning and Teaching. Draft for consultation, May 2012. Available at: http://www.qaa.ac.uk/Publications/InformationAndGuidance/Pages/learningteaching-consultation.aspx (Accessed: 25 June 2012).

Schreiner, L. (2010) 'Factors that contribute to sophomore success and satisfaction', in Hunter, M., Tobolansky, B., Gardner, J., Evenbeck, S., Pattensgale, J., Schaller, M. and Schriver, L. (eds.), Helping sophomores succeed: understanding and improving second-year experiences. San Francisco: John Wiley and Sons, pp. 4365.

Tariq, V., Scott, E.M., Cochrane, A.C., Lee, M. and Ryles, L. (2004) 'Auditing and mapping key skills within university curricula', Quality Assurance in Education, 12(2), pp. 70-81.

University Teaching and Learning Committee (UTLC) reference? 
Wingate, U. (2006) 'Doing away with 'study skills", Teaching in Higher Education, 11(4), pp. 457-469.

Wingate, U., Andon, N. and Cogo, A. (2011) 'Embedding academic writing instruction into subject teaching: a case study', Active Learning in Higher Education, 12(1), pp. 6981.

Yorke, M. (2006) 'Employability in higher education: what it is -what it is not'. Learning and Employability Series One. York: Higher Education Academy [Online] Available at: http://www.heacademy.ac.uk/assets/documents/tla/employability/id116 employabilit $y$ in higher education 336.pdf (Accessed: 10 February 2012).

\section{Author details}

Dr Pat Hill is a Senior lecturer and Academic Skills Tutor in the School of Music, Humanities and Media at the University of Huddersfield. She chairs a Task and Finish Group on embedding skills that is part of the ALDinHE Continuing Professional Development working group.

Dr Amanda Tinker is a Senior lecturer and Academic Skills Tutor in the School of Art, Design and Architecture at the University of Huddersfield. She is Learning Development Team leader for the School. 


\section{Appendix $1 \quad$ Initial Survey via LDs}

Promoting the Integration of Learning Development into the Student Experience. What we hope to achieve:

To inform, encourage and support academic staff in embedding learning development within the curricula.

To produce a repository of good practice.

The first step is gathering information

ASTs - What is happening in your School?

Library staff - What are you involved in?

Survey of academic staff

\section{Rationale:}

This project is underpinned by the idea of a student experience which develops attributes which will enable students at all levels to make the most of their study and prepare them for future employment.

Whilst valuing interventions and opportunities offered to students in such forms as Academic Skills provision; PDP; Personal Tutoring; and PAL, this project is exploring ways that learning development can be embedded within the curriculum. This embedding is designed to eliminate problems associated with engaging students in learning development by incorporating activities into their mainstream activities.

Embedding does not mean simply including these abilities in learning outcomes but specifically designing opportunities for development within a module and providing the necessary input or guidance to enable such development.

Learning development in this instance includes academic, information literacy and employability skills. 
The survey is designed to elicit examples of good practice which can be used to develop a framework and toolkit to encourage and enable colleagues to include learning development within modules. The following is a list of undergraduate and graduate skills and attributes; it has been compiled from various sources but is not exhaustive so feel free to add to the list if necessary. Identify where these skills are taught and how; this may be already fully or partly embedded or bolt-on:

$\begin{array}{lccc}\text { critical thinking } & \text { self-reflection } & \text { note-making skills } & \text { information literacy } \\ \text { oral communication } & \text { formal writing skills } & \text { interpersonal skills, } \\ \text { identifying and solving problems } & \text { leadership } & \text { computer literacy } \\ \text { producing an argument } & \text { referencing } & \text { teamwork } & \text { organisation }\end{array}$




\section{Appendix 2}

\section{Mapping Template}

TT = Taught by module tutor

TAS = Taught by Academic Skills Staff

$\mathrm{P}=$ Practised

LS = Input from library staff

(The current version also includes $A=$ Assessed)

\begin{tabular}{|c|c|c|c|c|c|c|}
\hline \multicolumn{7}{|l|}{ LEVEL: } \\
\hline Module Titles & Module & Module & Module & Module & Module & Module \\
\hline \multicolumn{7}{|l|}{ Critical Thinking } \\
\hline \multicolumn{7}{|l|}{ Self-reflection } \\
\hline \multicolumn{7}{|l|}{ Note-making skills } \\
\hline \multicolumn{7}{|c|}{ Oral communication } \\
\hline \multicolumn{7}{|l|}{ Formal writing skills } \\
\hline \multicolumn{7}{|l|}{ Interpersonal skills } \\
\hline \multicolumn{7}{|c|}{$\begin{array}{l}\text { Identifying and solving } \\
\text { problems }\end{array}$} \\
\hline \multicolumn{7}{|l|}{ Leadership } \\
\hline \multicolumn{7}{|l|}{ Teamwork } \\
\hline \multicolumn{7}{|l|}{ Organisation } \\
\hline \multicolumn{7}{|l|}{$\begin{array}{l}\text { Producing an } \\
\text { argument }\end{array}$} \\
\hline \multicolumn{7}{|l|}{ Referencing } \\
\hline \multicolumn{7}{|l|}{ Information literacy } \\
\hline Computer literacy & & & & & & \\
\hline
\end{tabular}

